\title{
USE OF ANYFLIP BEKEL LONGAN E-BOOK TO IMPROVE LITERATION SKILLS OF V-GRADE STUDENTS IN KEDUNGREJO ELEMENTARY SCHOOL 2 IN PANDEMIC
}

\author{
Martin Indah ${ }^{1^{*}}$ \\ ${ }^{1}$ SDN 2 Kedungrejo, Lamongan, East java, Indonesia \\ imada004@gmail.com
}

DOI: https://doi.org/10.21107/Widyagogik/v8i2. 9583

Received November 30, 2020; Revised December 16, 2020; Accepted January 16, 2021

\section{Abstract}

The purpose of this study was to determine the extent to which students' language literacy skills, especially the reading skills of students, using E-Book Anyflip with Local Wisdom in Lamongan during the pandemic. This type of research is classroom action research adopting the Kemmis and Mc. Taggart. This research uses 3 types of data (learning implementation data, student learning outcomes data, and data on constraints encountered in learning activities). The research was conducted in class V SDN 2 Kedungrejo, Modo District, Lamongan Regency. This research was conducted in two cycles, the research subjects were the fifth grade students of SDN 2 Kedungrejo in the second semester of the 2019/2020 academic year with a total of 13 students (8 male and 5 female). The results of this study were $100 \%$ learning implementation cycle I and II. The achievement of teacher activities in learning in cycle I was 75 , while in cycle II it was 87.5. The class average value of student literacy learning outcomes in the first cycle was 67.5. Meanwhile, in cycle II the average value of student literacy learning outcomes increased to 78.8. Classical learning completeness of students' literacy learning outcomes in the first cycle obtained a percentage of $69.23 \%$ and was included in the high category. Meanwhile, classical learning completeness in cycle II obtained a percentage of $92.3 \%$. The conclusion of this study is the reading skills of students in using E-Book Anyflip with Local Wisdom in Lamongan during the pandemic are very good based on the 3 types of data used.

Keywords - E-Book, Anyflip Bekel Longa, Literation Skills. 
2 Use of Anyflip Bekel Longan E-Book to Improve Literation Skills of V-Grade Students in Kedungrejo Elementary School 2 in Pandemic

Martin Indah

\section{Introduction}

Life in the 21st century requires a person to master a variety of skills. Everyone must be able to master critical thinking skills, creative thinking, flexible problem solving, collaborating and innovating and communicating so that they are expected to be successful in work and in life. Schools which are at the forefront of education and learning are challenged to prepare students to face various challenges in that century. Therefore, learning in the 21st century must be student-centered, collaborative, contextual, and integrated with society (Zubaidah, 2016).

In addition to the four higher-order thinking skills above, another skill that students must master in facing the challenges of the 21st century is literacy skills. Literacy is an activity that is closely related to the world of education and learning in schools. Through this literacy activity, students begin to recognize, understand, and apply the knowledge they acquire in learning activities and daily life, both at home, at school, and in the surrounding environment.

Literacy skills are one of the language skills. Literacy skills are skills related to written language, namely reading and writing skills. Literacy skills require students to master writing or letters, both receptively and expressively. In addition, it also requires students to seek, trace, process, and understand information to analyze, respond to, and use written texts to achieve goals, develop understanding and potential, and to participate in the social environment. Schools as the spearhead of the implementation of literacy activities are expected to be able to make students active readers and writers. Literacy mastery shows the language proficiency of each student. Therefore, literacy is seen as a means that can be used to obtain and communicate information.

Literacy skills, which include reading and writing skills, are believed to be able to form independent individuals and be able to adapt to developments in science and technology (USAID, 2014: 25). Through literacy learning, students are expected to have a high level of understanding and thinking ability from an early age, not just literal understanding. In that context, literacy learning in the high class plays a very important role. However, currently the literacy skills of Indonesian children are still very low. Chairman of the Indonesian Literacy Culture Development Forum, Satria Darma (in Yulaningsih, 2014) said that based on a survey conducted by many international institutions, it shows that the literacy culture of Indonesian people is far behind other countries in the world.

Research results from the Human Development Index (HDI) state that Indonesia ranked 110 out of 173 countries in the field of literacy in 2002. And in 2009, that position dropped one level to 111 . Meanwhile, based on the results of the Progress in International Reading Literacy Study (PIRLS) in the field of literacy competence stated that Indonesian elementary school (SD) students ranked 62 out of 74 countries in 2010. Indonesia is only better than Qatar, Kuwait, and Azarbaizan, but below Malaysia, Thailand, and very far from Singapore (Hasanudin, 2014). 
When referring to the results of the PISA research, the position of the literacy culture of Indonesian students is even worse. Indonesia ranks 64 th out of 65 countries studied in 2012. Meanwhile, Vietnam ranks in the top 20. In the same study, PISA also placed the reading culture of Indonesian students in the 57th position of the 65 countries studied (Satria Darma in Yulaningsih, 2014).

One of the competency standards for Indonesian in the 2013 Curriculum for elementary school grade $\mathrm{V}$ is "3.5 Digging important information from historical narrative texts presented orally and in writing using the following aspects: what, where, when, who, why, and how and 4.5 Presenting important information from historical narrative texts using aspects: what, where, when, who, why, and how as well as standard vocabulary and effective sentences (Permendikbud No. 37 Tahun 2018). The purpose of the basic competencies above is for students to have literacy skills, namely reading and writing skills. However, there are still students of grade $V$ elementary school 2 Kedungrejo who have not fully understood the contents of the historical narrative text that have been read and have not been able to rewrite the contents of historical narrative text that have been read in their own language. This fact is supported by the low learning outcomes of students in learning literacy skills. As many as $61.53 \%$ of the 13 students had not reached the predetermined minimum completeness criteria.

If these problems are not immediately resolved and allowed to continue, it can be said that learning Indonesian, especially literacy, has not encouraged an increase in language skills and knowledge of students. Whereas in the 2013 curriculum it is stated that Indonesian language learning from elementary school to high school in its implementation uses a text-based approach (Mahsun in Napitupulu, 2013). The use of a text-based approach really requires literacy skills, which include reading and writing skills.

Meanwhile, entering 2020, various parts of the world were shocked by the Covid19 virus disaster. Covid-19 or better known as the corona virus is a virus that attacks the respiratory system in humans. This corona virus can cause minor disorders of the respiratory system, severe lung infections, and death. As a result of this pandemic, all sectors are feeling the impact, including the education system in Indonesia.

In response to this incident, the government immediately imposed social restrictions / social distancing / physical restrictions / physical distancing to suppress the spread of the Covid-19 virus until a decision was made to work from home. The implementation of this decision affects the world of education, in which the Ministry of Education and Culture also implements the decision to study from home in accordance with Circular No. 4 of 2020 from which recommends that all activities in educational institutions must be kept at a distance and all material delivery will be delivered in their respective homes.

This also causes thematic learning in grade $V$ of elementary school 2 Kedungrejo, Modo District, Lamongan Regency to be carried out online. Learning in a network is a 
4 Use of Anyflip Bekel Longan E-Book to Improve Literation Skills of V-Grade Students in Kedungrejo Elementary School 2 in Pandemic

Martin Indah

learning activity that is carried out without direct face-to-face / meetings between teachers and students, but is carried out using the internet network. Teachers must continue to carry out and ensure learning activities take place even though they do not meet directly with students, each of whom is at home. In addition, teachers are required to be able to design innovative learning activities by utilizing online media. Therefore, it takes interesting learning resources that can be used by students in improving language literacy skills, especially learning resources that contain local wisdom in Lamongan but still support online learning activities. One of the communication applications that support online learning activities is the zoom meeting application. Zoom meeting is a communication application using video (Dewi, 2020). These applications can be used in a variety of mobile devices, desktop, to telephone and space systems.

In connection with the low literacy skills of class $V$ elementary school 2 Kedungrejo students and the Covid-19 virus pandemic which forces learning activities to be carried out in a network and the importance of introducing Lamongan local wisdom to students through the texts being studied, the solution is made by the classroom teacher is using the e-book Anyflip containing local wisdom of Lamongan (bekel longan) in literacy learning. E-book anyflip bekel longan is an electronic book (abbreviated as e-book or ebook) or a digital book or an electronic version of a book made using the anyflip application where the material presented in it contains historical narrative text containing local wisdom of Lamongan.

The purpose of this study was to determine the extent to which students 'language literacy skills, especially students' reading skills, in using the Anyflip e-Book with Local Wisdom in Lamongan during the pandemic.

\section{Method}

\subsection{Place, Time, and Research Subjects}

The research was conducted in class $V$ Elementary School 2 Kedungrejo, Modo District, Lamongan Regency. This research was carried out in two cycles, cycle I on April 8 and 92020 and cycle II on April 15 and 16 2020. The research subjects were students of class V Kedungrejo 2 elementary school semester II of the 2019/2020 school year with 13 students, consisting of 8 male students and 5 female students.

\subsection{Research Procedures}

This type of research is classroom action research. This study uses the Kemmis and Mc. Taggart. This research procedure consists of planning, action, observation, and reflection (Rochiati, 2008).

\subsection{Data Collection Techniques}

This research uses 3 types of data, namely learning implementation data, student learning outcomes data, and data on constraints encountered in learning activities. Data regarding the implementation of learning or teacher activities during the learning 
process is obtained by observation. This observation activity was carried out by 2 observers from fellow researchers using observation guidelines in the form of a format or checklist as a reference for assessment. Data regarding student learning outcomes is obtained through the final test assessment at each meeting. The final test is done in writing, the tools are a. items with a form that refers to Barret's taxonomy and $b$. The evaluation sheet contains the command to rewrite the contents of the historical narrative text that has been read in their own language. The items are used to measure literacy skills in terms of reading while the evaluation sheet is used to measure literacy skills in terms of rewriting the contents of historical narrative text that have been read in their own language. The following is a guideline for scoring aspects of student literacy assessment. Data regarding the obstacles encountered in learning activities is obtained by recording events that occur during the implementation of learning using field note sheets.

\subsection{Data Analysis}

Data analysis on observational data and field notes was carried out qualitatively while test result data was carried out quantitatively.

\subsubsection{Data Analysis of Observation Results}

Analysis of the data from these observations was obtained from the observations of researchers as class teachers and fellow researchers. Researchers and fellow researchers fill out observation sheets during the learning process.

The learning implementation is analyzed using the formula:

$$
\text { Percentage of learning implementation }=\frac{\sum \text { score obtained }}{\sum \text { maximum score }} \times 100 \%
$$

After calculating the percentage, the existing data were interpreted using qualitative sentences, as follows.

$$
\begin{aligned}
& 80 \%-100 \%=\text { very good } \\
& 66 \%-79 \%=\text { good } \\
& 56 \%-65 \%=\text { enough } \\
& 40 \%-55 \%=\text { less } \\
& 30 \%-39 \%=\text { failed }
\end{aligned}
$$

The achievement of learning scores was analyzed using the formula:

$$
\text { Achievement value }=\frac{\sum \text { score obtained }}{\sum \text { maximum score }} \times 100
$$

After calculating the achievement value, the existing data is interpreted with a qualitative sentence, as follows. 
6 Use of Anyflip Bekel Longan E-Book to Improve Literation Skills of V-Grade Students in Kedungrejo Elementary School 2 in Pandemic

Martin Indah

$80-100=$ very good

$66-79=$ good

$56-65$ = enough

$40-55=$ less

$30-39=$ failed

\subsubsection{Analysis of Test Result Data}

Individual Assessment Formulas

$$
\text { Final score }=\frac{\sum \text { score obtained }}{\sum \text { maximum score }} \times 100
$$

After calculating the final score, the existing data are interpreted with qualitative sentences, as follows.

$\geq 65-100=$ complete

$<65=$ incomplete

Class Average

$$
\bar{x}=\frac{\sum \text { all student grades }}{\sum \text { students }}
$$

Classical Completeness Formulas

$$
p=\frac{\sum \text { students who have completed learning }}{\sum \text { students }} \times 100 \%
$$

With the descriptor as follows.

$$
\begin{aligned}
& >80 \%=\text { very high } \\
& 60 \%-79 \%=\text { high } \\
& 40 \%-59 \%=\text { moderate } \\
& 20 \%-39 \%=\text { low } \\
& <20 \%=\text { very low }
\end{aligned}
$$

\subsubsection{Field Notes}

The field note sheet contains the results of field notes which are then analyzed by observing every input submitted by the observer, looking for weaknesses or shortcomings during the learning process and how to overcome these weaknesses so that at the next meeting they do not happen again so that the learning process runs smoothly. 


\subsection{Research Indicators}

The indicators of success in this study are when the implementation of learning activities which are manifested in learning activities by the teacher reaches $80 \%$ with an achievement score of 80; Student learning outcomes show that as many as $75 \%$ of students have completed learning with a minimum completeness criteria score of 65 (Suharsimi, 1993); and all forms of obstacles that arise can be overcome, so that learning objectives can be achieved.

\section{Result and Discussion}

The use of e-book Anyflip beker longan in grade $V$ elementary school 2 Kedungrejo achieved the expected results. Teaching and learning activities in the network run well through the video zoom meeting based communication application. Teacher activity and student literacy learning outcomes in cycle II increased compared to cycle I. Based on observations of teacher activity in cycle I, the average value of the achievement of teacher activity obtained a total value of 75 and was categorized as good. However, the average achievement value has not yet reached the achievement value determined on the success indicator, which is $\geq 80$ (Djamarah, 2005: 97). This is because teachers have not been able to manage time and condition students properly, so that learning activities are not carried out optimally.

The quality of learning and the level of achievement of teacher activities in the first cycle were improved and improved in the second cycle. In cycle II, the average value of the achievement of teacher activities obtained a total value of 87.5. The value acquisition is included in the very good category. The results of the achievement of teacher activities in cycle II have reached the specified success indicators and have increased compared to cycle I. The teacher has implemented literacy learning steps using the e-book Anyflip beker longan in the network.

Based on the results of observations of teacher activities in cycle I and cycle II, each activity has been carried out and obtained a value of $100 \%$ feasibility. The acquisition of this value is categorized as very good (Djamarah, 2005: 97). The results of the implementation of teacher activities in cycles I and II can be seen in the diagram as follows. 


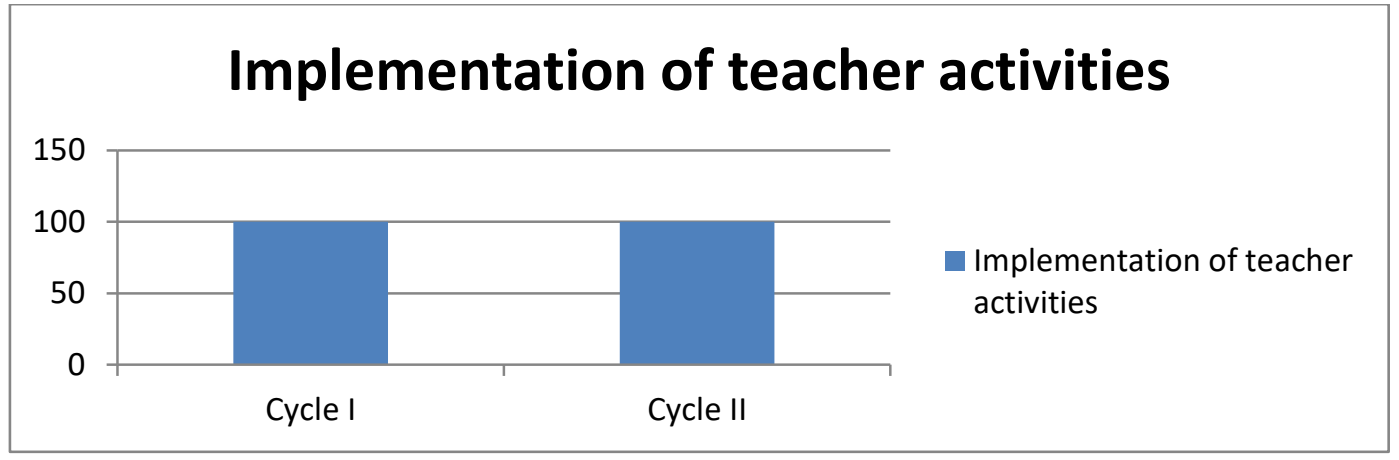

Figure 1. The diagram of Implementation of Teacher Activities in the Implementation of Literacy Learning for Class V Students in Elementary School 2 Kedungrejo using E-Book Anyflip Beker Longan

The comparison of the results of teacher activity achievement in cycle I and cycle II can be seen in the following diagram.

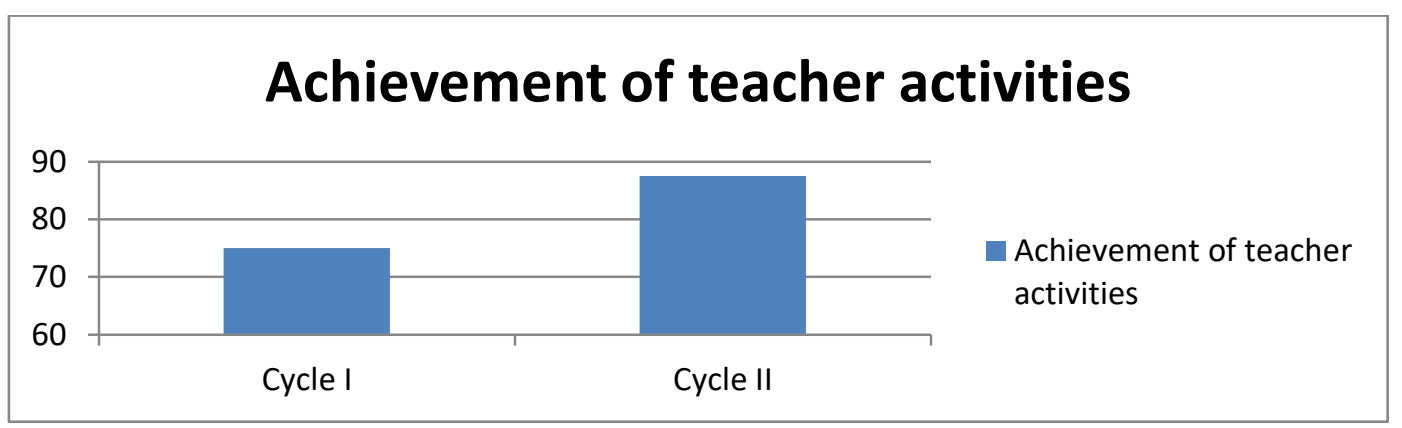

Figure 2. The diagram of Achievement of Teacher Activities in the Implementation of Literacy Learning for Class V Students in Elementary School 2 Kedungrejo using E-Book Anyfliip Beker Longan

The average value of student literacy results in cycle I and cycle II can be seen in the following diagram.

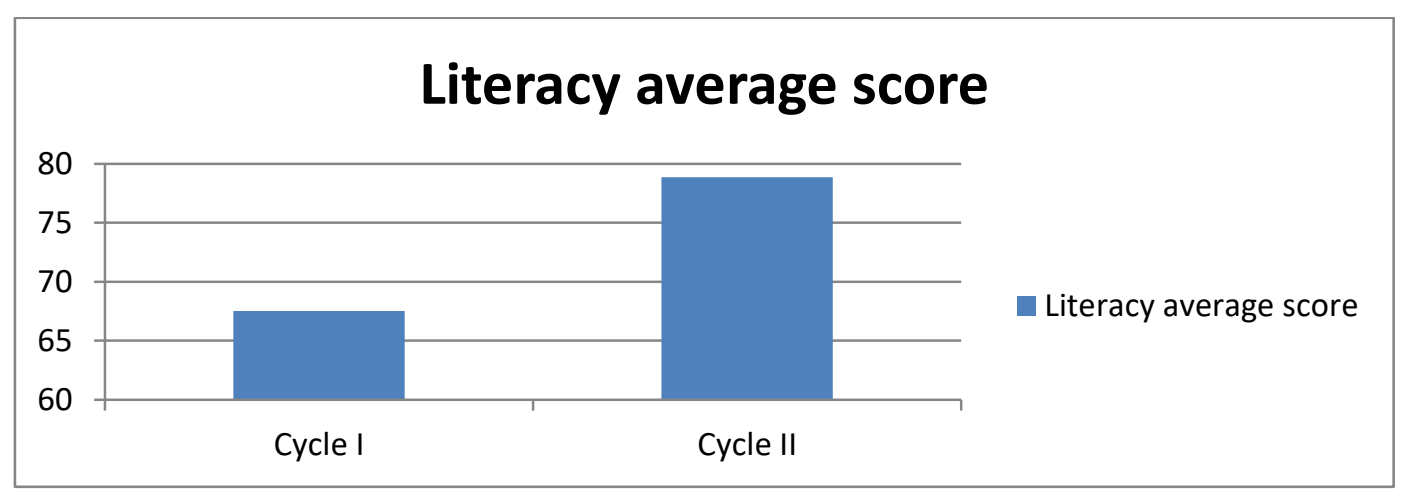

Figure 3. The diagram of average Value of Literacy Results for Class $V$ Students in Elementary School 2 Kedungrejo using E-Book Anyfliip Beker Longan 
From diagram 3 in the first cycle, the average value is 67.5 , while in the second cycle, the students' average score has increased by 11.34 , so that the average value is 78.84 .

In cycle II, there was an increase compared to cycle I. Classical learning completeness from the results of student literacy in cycle I obtained $69.23 \%$ (9 out of 13 students experienced learning completeness) and was included in the high category. Nevertheless, students' literacy learning using the e-book Anyflip beker longan in the network in the first cycle was said to be incomplete. Learning is said to be classically complete if $\geq 75 \%$ of all students in the class have finished learning (Djamarah, 2005 : 263). The completeness of classical learning results of students' literacy was improved and improved in cycle II. In cycle II, the percentage of classical learning completeness has increased by $23.07 \%$ so that the percentage of completeness learning is $92.3 \%$ (12 students out of 13 students experienced learning completeness). This means that it has reached the predetermined success indicators and is included in the very high category. The percentage of classical learning completeness results in cycle I and cycle II can be seen in the following diagram.

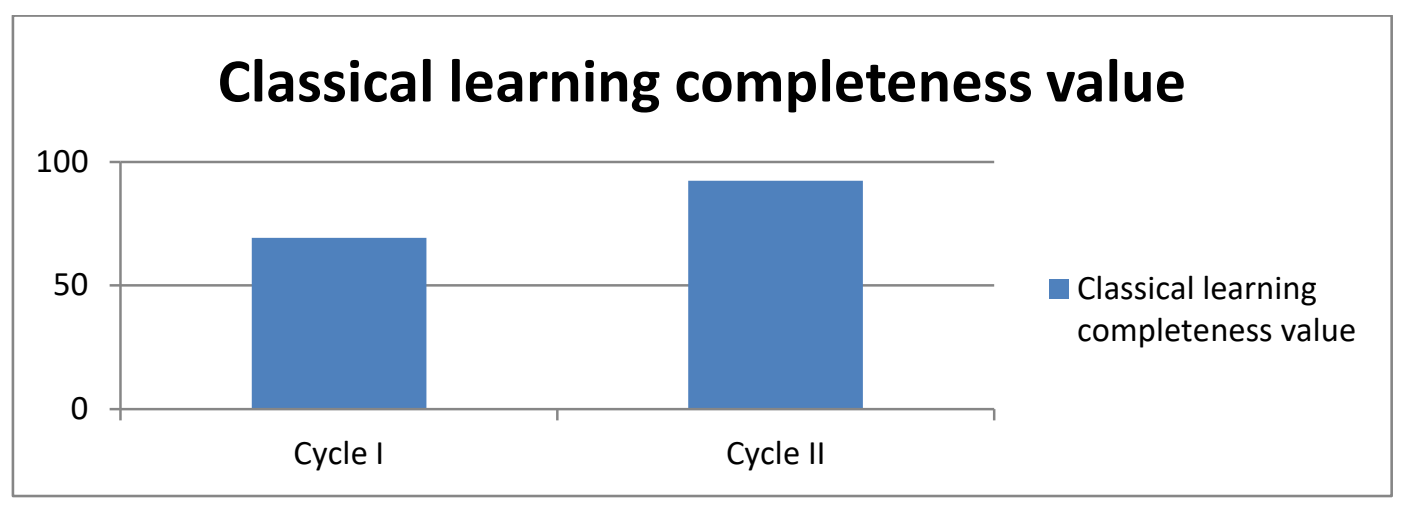

Figure 4. The Diagram of Completion of Classical Learning Literacy for Class V Elementary School 2 Kedungrejo Students using E-Book Anyfliip Beker Longan

Based on the facts above, that the use of e-book Anyflip beker longan in the network can improve the literacy skills of Class $V$ students in elementary school 2 Kedungrejo. Because the use of e-book Anyflip works long in the network, the learning process emphasizes student activity; The learning process is designed according to the characteristics of students so that students in learning become more enthusiastic, motivated, comfortable and enjoyable. In addition, in presenting information packaged in the form of e-book Anyflip using language that is communicative and easily understood by grade $V$ elementary school students; the information presented is in accordance with the cognitive development of grade $V$ elementary school students; and the sentences used are more simple word choices and easy to understand for fifth grade elementary school students; attractive display design, both in terms of color and images with color elements that are displayed harmoniously; use illustrations, pictures, and photos that are attractive and in accordance with each discussion of the material in the 
10 Use of Anyflip Bekel Longan E-Book to Improve Literation Skills of V-Grade Students in Kedungrejo Elementary School 2 in Pandemic

Martin Indah

book so that students are stimulated to actively read and can rewrite the contents of the text that has been read in their own language.

\section{Conclusion}

Based on the results of data analysis in this study regarding the use of e-book Anyflip beker longan in class V Elementary School 2 Kedungrejo, it can be seen that the learning process is going very well. This can be seen from the implementation of learning both in cycle I and cycle II which reached $100 \%$. In addition, the value of learning achievement using the e-book Anyflip beker longan is very good.

The value of the achievement of teacher activities in learning in cycle I was 75, while in cycle II it was 87.5. The results of learning literacy skills of fifth grade students of Elementary School 2 Kedungrejo after the learning process using the e-book Anyflip beker longan also increased. The increase in student learning outcomes can be seen from the class average value and classical learning completeness. The class average value of student literacy learning outcomes in the first cycle was 67.5. Meanwhile, in cycle II the average value of student literacy learning outcomes increased to 78.8. Classical learning completeness of students' literacy learning outcomes in the first cycle obtained a percentage of $69.23 \%$ and was included in the high category. Meanwhile, classical learning completeness in cycle II obtained a percentage of $92.3 \%$. This acquisition is included in the very high category.

Constraints in the implementation of student literacy learning by using the e-book Anyflip beker longan, namely the management of the learning implementation time was not according to plan, the teacher could not condition the students well. It is better if the teacher can manage the time as needed, so that the management of the learning implementation time is according to the plan.

The suggestion to be conveyed through this research is that students are always motivated to be active in learning activities even in networks and during the pandemic, teachers should use learning media in learning activities and always involve students in the learning process and the principal should provide motivation, support, and appreciation. for teachers to innovate in the implementation of learning and selfdevelopment activities.

\section{References}

Dewi, Dinda S. 2020. Mengenal Aplikasi Meeting Zoom: Fitur dan Cara Menggunakannya. https://tirto.id/mengenal-aplikasi-meeting-zoom-fitur-dan-caramenggunakannya-eGF7

Hasanudin, D. $\quad$ R. $2014 . \quad$ Literasi dan Kita. http://www.bandungmagazine.com/analysis/literasi-dan-kita. (diakses 21 Januari 2020)

http://m.kompas.com/read/2013/02/26/21303951/Pembelajaran.Bahasa.Indonesia. Menggunakan.Pendekatan.Teks (diakses 18 Januari 2020) 
https://anyflip.com/

https://id.wikipedia.org/wiki/Buku_elektronik

Napitupulu, E. L. 2013. Pembelajaran Bahasa Indonesia Menggunakan Pendekatan Teks. https://edukasi.kompas.com/read/2013/02/26/21303951/Pembelajaran.Bahasa.Ind onesia.Menggunakan.Pendekatan.Teks

Permendikbud No. 37 Tahun 2018

Surat Edaran No. 4 Tahun 2020

USAID. 2014. Pembelajaran Literasi Kelas Awal di LPTK: Buku Sumber bagi Dosen LPTK. Jakarta: USAID

Yulaningsih. 2014. Literasi Indonesia Sangat Rendah. http://m.republika.co.id/berita/koran/didaktika/14/12/15/ngm3g840-literasiindonesia-sangat-rendah. (diakses 21 Januari 2020)

Zubaidah, Siti. 2016. Keterampilan Abad Ke-21: Keterampilan yang Diajarkan Melalui Pembelajaran. Seminar Nasional Pendidikan dengan tema "Isu-isu Strategis Pembelajaran MIPA Abad 21At: Program Studi Pendidikan Biologi STKIP Persada Khatulistiwa $\quad$ Sintang - Kalimantan Barathttps://www.researchgate.net/publication/318013627_KETERAMPILAN_ABAD_ KE-21_KETERAMPILAN_YANG_DIAJARKAN_MELALUI_PEMBELAJARAN

(C) 2020 by the authors. Submitted for possible open access publication under the terms and conditions of the Creative Commons Attribution ShareAlike (CC BY SA) license (https://creativecommons.org/licenses/by-sa/4.0/). 